\title{
Protective effects of dexmedetomidine and remote ischemic preconditioning on renal ischemia reperfusion injury in rats
}

\author{
Cansu Balcı, M.D., ${ }^{1}$ Mert Akan, M.D., ${ }^{2}$ Nilay Boztaş, M.D., ${ }^{3}$ Sevda Özkardeşler, M.D., ${ }^{3}$ \\ Bekir Uğur Ergür, M.D., ${ }^{4}$ Mustafa Ensari Güneli, M.D., ${ }^{5}$ Belgin Ünal, M.D. ${ }^{6}$
}

\begin{abstract}
1'Department of Anesthesiology and Reanimation, Çanakkale State Hospital, Çanakkale-Turkey
${ }^{2}$ Department of Anesthesiology and Reanimation, Kent Hospital, İmir-Turkey

${ }^{3}$ Department of Anesthesiology and Reanimation, Dokuz Eylül University Faculty of Medicine, İzmir-Turkey

${ }^{4}$ Department of Histology and Embryology, Dokuz Eylül University Faculty of Medicine, İzmir-Turkey

${ }^{5}$ Department of Laboratory Animal Science, Dokuz Eylül University Faculty of Medicine, İzmir-Turkey

${ }^{6}$ Department of Public Health, Dokuz Eylül University Faculty of Medicine, Izmir-Turkey
\end{abstract}

\begin{abstract}
BACKGROUND: The aim of this study was to evaluate the effects of remote ischemic preconditioning (RIPC) and dexmedetomidine as pharmacological conditioning in a rat renal ischemia/reperfusion (IR) injury model.

METHODS: Total of 28 male Wistar Albino rats weighing 250 to $300 \mathrm{~g}$ were divided into 4 equal groups. Group I (Sham; $\mathrm{n}=7$ ): Laparotomy and renal pedicle dissection were performed, and the rats were observed under anesthesia without any intervention. Group II (IR; n=7): Following laparotomy and 45 minutes of left renal pedicle occlusion, 4 hours of reperfusion was performed. Group III (IR+D; n=7): Following laparotomy and ischemia, dexmedetomidine was administrated intraperitoneally $(\mathrm{I} 00 \mu \mathrm{gg} / \mathrm{kg})$ at fifth minute of reperfusion. Group IV (RIPC+IR; n=7): Under anesthesia, 3 cycles of ischemic preconditioning were applied to the left hind leg, and after 5 minutes, renal IR was performed. All rats were sacrificed after the left kidney was processed for conventional histomorphology.
\end{abstract}

RESULTS: Total histomorphological renal injury score was significantly lower in the Sham group compared with the other groups $(p<0.0 I)$. Total renal injury score of IR group was significantly higher than IR+D and RIPC+IR groups $(p<0.0 I)$. There was no significant difference in the total renal injury score between the dexmedetomidine and RIPC groups $(P=0.89)$.

CONCLUSION: In the present study, it was demonstrated histomorphologically that both dexmedetomidine and RIPC decreased renal IR injury significantly. In addition, no significant difference was found between dexmedetomidine and RIPC groups.

Keywords: Dexmedetomidine; ischemia reperfusion injury; kidney; remote ischemic preconditioning.

\section{INTRODUCTION}

Ischemia is defined as the partial or total restriction of blood flow to a certain tissue or organ for a limited period of time, and reperfusion is the restoration of blood flow. Restoration of blood flow can be even more harmful to tissues than the

\begin{tabular}{|c|c|}
\hline \multicolumn{2}{|c|}{$\begin{array}{l}\text { Address for correspondence: Cansu Balcı, M.D. } \\
374 \text { Sokak, Görgün Sitesi, No: 7, İris Apt., D: I, Salihli, Manisa, Turkey }\end{array}$} \\
\hline Tel: +90 $236-7131500$ & E-mail: cansubal35@hotmail.com \\
\hline Submitted: 02.03 .2016 & Ulus Travma Acil Cerrahi Derg \\
\hline Accepted: 04.10 .2016 & $2017 ; 23(4): 279-286$ \\
\hline 回蚂回 & doi: $10.5505 /$ tjtes. 2016.49103 \\
\hline 口? & $\begin{array}{l}\text { Copyright } 2017 \\
\text { TJTES }\end{array}$ \\
\hline
\end{tabular}

ischemic injury. ${ }^{[l]}$ Severity of ischemia/reperfusion (IR) injury depends on ischemic duration and adequacy of collateral circulation. IR injury is commonly encountered in various clinical conditions, such as ischemic cerebrovascular accident, myocardial infarction, cardiopulmonary resuscitation, and tourniquet application. ${ }^{[2]}$ During the ischemic period, related tissue synthesizes excessive amounts of toxic, free oxygen radicals. Free oxygen radicals are known to play a critical role in the physiopathology of IR damage. ${ }^{[3,4]}$

During reperfusion, free oxygen radicals cause endothelial damage, elevated microvascular permeability, and tissue edema. ${ }^{[5,6]}$ Furthermore, activated adhesion molecules and cytokines may trigger systemic inflammatory response syndrome. ${ }^{[7]}$ These toxic substances may in turn lead to multiple organ failure, which may require long-term intensive care due to damage in remote organs, such as the lungs, kidneys, and heart. ${ }^{[8,9]}$ 
Various methods have been developed to prevent such damage. Ischemic preconditioning (IPC) and pharmacological conditioning are the most commonly used methods. IPC has been defined as a process that increases tissue resistance to long-term ischemia via reperfusion periods following short ischemic episodes. ${ }^{[10]}$ It is categorized in 2 groups: direct and remote IPC (RIPC). In direct IPC, the organ is subjected to short-term IR episodes before long-term ischemia. In IPC, ischemia is maintained in remote organ other than the organ to be protected. ${ }^{[I]}$ Another method used to prevent or reduce IR damage is pharmacological pre- and postconditioning. Dexmedetomidine is an alpha2-adrenergic receptor agonist and wide-spectrum sedative and analgesic drug commonly used in intensive care settings. ${ }^{[2]}$ Trials using ischemic and inflammatory response models have demonstrated that dexmedetomidine has an anti-inflammatory effect with protective properties against IR injury. ${ }^{[13]}$ In this study, the aim was to compare the effects of pharmacological postconditioning with dexmedetomidine and IPC in an experimental rat model of renal IR injury.

\section{MATERIALS AND METHODS}

The present study was performed at the experimental animal laboratory of 9 Eylül University. Experimental protocols and animal care methods used were approved by the institutional experimental animal research committee.

Twenty-eight adult male Wistar Albino rats weighing 250 to $300 \mathrm{~g}$ were used in this study. The rats were housed with 12 hour light/dark cycle at room temperature under $40 \%$ to $60 \%$ relative humidity, fed standard pellet diet, and provided with water. Access to food and water was unlimited. Anesthesia was achieved with $50 \mathrm{mg} / \mathrm{kg}$ intraperitoneal (ip) ketamine and $10 \mathrm{mg} / \mathrm{kg}$ xylazine hydrochloride. The animals were randomly separated into 4 groups of 7 rats.

Group I (Sham; $\mathbf{n = 7 ) : ~ A b d o m i n a l ~ d i s s e c t i o n ~ w a s ~ p e r f o r m e d ~}$ at 65th minute of anesthesia protocol, left renal pedicle was dissected, and the rats were kept under anesthesia for an additional 285 minutes without any further intervention.

Group II (IR; $\mathbf{n = 7 ) : ~ A b d o m i n a l ~ d i s s e c t i o n ~ w a s ~ p e r f o r m e d ~ a t ~}$ 65 th minute of anesthesia protocol, left kidney was subjected to total ischemia for 45 minutes followed by reperfusion for 4 hours.

Group III (IR+D; $\mathbf{n = 7})$ : Abdominal dissection was performed at 65th minute of anesthesia protocol, left kidney was subjected to IR (45 minutes ischemia +4 hours reperfusion), and $100 \mu \mathrm{g} / \mathrm{kg}$ ip dexmedetomidine (Precedex $100 \mathrm{mcg} / 2 \mathrm{~mL}$ vial; Abbott Laboratories, Lake Bluff, IL, USA) was injected 5 minutes after reperfusion.

Group IV (RIPC+IR; $\mathbf{n = 7}$ ): Following abdomen dissection, 3 cycles of 10 minutes ischemia +10 minutes reperfusion combination was applied to left hind leg. Five minutes later, procedure described in Group II was performed.

Exposing left renal pedicle in Group I, and initiating ischemia at the 65th minute of anesthesia in Groups II and III, was intended to synchronize all groups to preconditioning time of Group IV and to standardize the beginning of the procedures. Tissue samples were obtained at the end of reperfusion.

\section{Experimental Study Design}

Following anesthesia protocol, each rat was fixed on the operating table in the supine position and the abdomen was dissected with median line incision. The left kidney was exposed, and the renal pedicle was dissected. In order to protect the rats from hypothermia, operating table was warmed with a heat lamp throughout the procedure. Body temperature was maintained at $37^{\circ} \mathrm{C}$ to $37.5^{\circ} \mathrm{C}$. Saline solution was delivered subcutaneously at $3 \mathrm{~mL} / \mathrm{kg} / \mathrm{h}$ dose to prevent dehydration. The abdomen was kept closed during IR.

\section{Renal Ischemia Reperfusion Model}

Left renal ischemia was induced by clamping the renal pedicle with atraumatic microvascular clamp. Adequate occlusion was verified by the absence of pulsation in the renal pedicle and paleness of the kidney. After completing ischemia duration, microvascular clamp was removed to permit reperfusion.

\section{Remote Ischemic Preconditioning Model}

Elastic bandage ( $1 \mathrm{~cm}$ width $\times 30 \mathrm{~cm}$ length) was rolled tightly around the left hind leg 3 times. Three cycles of 10 minutes of ischemia +10 minutes of reperfusion were applied. Blockage of blood flow was verified with a laser flowmeter.

In all groups, the left kidney was removed for histomorphological examination at the end of the total study period and the rats were sacrificed via exsanguination (cardiac puncture). Tissue samples were fixed in 10\% buffered formaldehyde and renal damage was assessed histologically.

\section{Histomorphological Evaluation of Renal Tissue}

Kidney samples were examined in blinded fashion in the histology-embryology department of the institution.

\section{Tissue Examination Protocol}

Kidney specimens were stained with hematoxylin-eosin for analysis of histomorphological properties and Masson's trichrome for connective tissue examination.

\section{Histomorphological Evaluation of Renal Tissue}

Sections were stained and examined under a light microscope. Images obtained from the samples were transferred to a computer using a high-resolution camera and evaluated thoroughly with a digital image analysis program. 
Renal sections with ischemic reperfusion were examined under a light microscope to evaluate structural changes in the proximal tubules (tubular atrophy, brush border loss, vacuolization, tubular dilatation, and cast formation), mononuclear cell infiltration, erythrocyte extravasation, interstitial structural changes, renal corpuscular morphology, and necrotic and apoptotic cells. Images obtained from the sections were scored semiquantitatively in terms of tubulointerstitial damage. Scoring was as follows: $0=$ none, $I=0-25 \%, 2=26-45 \%$, $3=46-75 \%$, 4=76-100\%.

\section{Exclusion Criteria}

Rats in need of resuscitation were to be excluded from the study.

\section{Statistical Analysis}

SPSS for Windows, Version 15.0 (SPSS Inc., Chicago, IL, USA) software was used for statistical analyses. Data analysis was performed with Kruskal-Wallis test. Paired comparisons were evaluated with Mann-Whitney $U$ test. Data were expressed as mean $\pm S D$. $P$ value $<0.05$ was accepted as statistically significant.

\section{RESULTS}

Total of 28 rats were included in the study and all of the rats completed the study. Histomorphological damage scores are provided in Table I, and comparative significance of the scores can be seen in Table 2.

Table I. Histomorphological damage scores of the groups

\begin{tabular}{|c|c|c|c|c|}
\hline & $\begin{array}{l}\text { Proximal tubule } \\
\text { damage scores }\end{array}$ & $\begin{array}{l}\text { Mononuclear } \\
\text { cell infiltration }\end{array}$ & $\begin{array}{l}\text { Erythrocyte extravasation } \\
\text { and capillary dilatation }\end{array}$ & $\begin{array}{l}\text { Histomorphological } \\
\text { damage total score }\end{array}$ \\
\hline & Mean $\pm S D$ & Mean $\pm S D$ & Mean $\pm S D$ & Mean \pm SD \\
\hline Group I (n=7) (Sham) & $0.00 \pm 0.00$ & $0.14 \pm 0.37$ & $0.28 \pm 0.48$ & $0.42 \pm 0.78$ \\
\hline Group II (n=7) (IR) & $2.28 \pm 0.48$ & $1.57 \pm 0.53$ & $2.42 \pm 0.78$ & $6.2 \pm 1.25$ \\
\hline Group III $(n=7)(I R+D)$ & $1.28 \pm 0.48$ & $1.14 \pm 0.37$ & $1.42 \pm 0.53$ & $3.85 \pm 0.89$ \\
\hline Group IV (n=7) (IR+RIPC) & $1.42 \pm 0.53$ & $1.14 \pm 0.37$ & $1.42 \pm 0.53$ & $4.00 \pm 1.15$ \\
\hline$P^{a}$ & $<0.001^{*}$ & $0.001^{*}$ & $0.001^{*}$ & $<0.001^{*}$ \\
\hline
\end{tabular}

IR: Ischemia reperfusion; D: Dexmedetomidine; RIPC: Remote ischemic preconditioning; SD: Standard deviation.

Table 2. Comparison of histomorphological damage scores with regard to significance

\begin{tabular}{|c|c|c|c|}
\hline & $\begin{array}{l}\text { Ischemia } \\
\text { reperfusion }\end{array}$ & $\begin{array}{l}\text { Ischemia reperfusion+ } \\
\text { dexmedetomidine }\end{array}$ & $\begin{array}{l}\text { Ischemia reperfusion+ } \\
\text { remote ischemic preconditioning }\end{array}$ \\
\hline \multicolumn{4}{|l|}{ Proximal tubule damage scores } \\
\hline Sham & $0.001^{*}$ & $0.001^{*}$ & $0.001^{*}$ \\
\hline Ischemia reperfusion & & $0.006^{*}$ & $0.015^{*}$ \\
\hline Ischemia reperfusion+dexmedetomidine & & & 0.59 \\
\hline \multicolumn{4}{|l|}{ Mononuclear cell infiltratio } \\
\hline Sham & $0.002^{*}$ & $0.002^{*}$ & $0.002^{*}$ \\
\hline Ischemia reperfusion & & 0.10 & 0.10 \\
\hline Ischemia reperfusion+dexmedetomidine & & & 1.00 \\
\hline \multicolumn{4}{|l|}{ Erythrocyte extravasation and capillary dilatation } \\
\hline Sham & $0.002^{*}$ & $0.005^{*}$ & $0.005^{*}$ \\
\hline Ischemia reperfusion & & $0.02^{*}$ & $0.02^{*}$ \\
\hline Ischemia reperfusion+dexmedetomidine & & & 1.00 \\
\hline \multicolumn{4}{|l|}{ Histomorphological damage total score } \\
\hline Sham & $0.001^{*}$ & $0.001^{*}$ & $0.00 I^{*}$ \\
\hline Ischemia reperfusion & & $0.005^{*}$ & $0.009^{*}$ \\
\hline Ischemia reperfusion+dexmedetomidine & & & 0.89 \\
\hline
\end{tabular}

${ }^{*} \mathrm{p}<0.05$ : Intergroup significant difference. aMann-Whitney $U$ test. 


\section{Renal Histomorphological Damage Score}

\section{Structural Changes in the Proximal Tubules}

The Sham group demonstrated a significantly lower histomorphological damage score compared with $I R, I R+D$, and RIPC+IR groups ( $p=0.001, p=0.001, p=0.001$, respectively). Comparison between IR, IR+D, and RIPC+IR groups revealed significant differences $(p=0.006, p=0.015$, respectively). IR group displayed significantly higher damage score compared with the IR+D and RIPC+IR groups, whereas no significant difference was determined between the $I R+D$ and $R I P C+I R$ groups $(p=0.59)$ (Fig. I).

\section{Mononuclear Cell Infiltration}

The Sham group demonstrated a significantly lower histomorphological damage score compared with the $I R, I R+D$, and RIPC+IR groups $(p=0.002, p=0.002, p=0.002$, respectively). No significant difference was found between the IR, IR+D and RIPC+IR groups ( $p=0.1, p=0.1$, respectively) (Fig. 2).

\section{Erythrocyte Extravasation and Capillary Dilatation}

The Sham group demonstrated a significantly lower histomorphological damage score compared with the $I R, I R+D$, and RIPC+IR groups $(p=0.002, p=0.005, p=0.005$, respectively). Comparison between the IR, IR+D, and RIPC+IR groups revealed significant differences $(p=0.02, p=0.02$, respectively). The IR group displayed a significantly higher damage score compared with the IR+D and RIPC+IR groups, whereas no significant difference was determined between the IR+D and RIPC+IR groups ( $p=I .00)$ (Fig. 3).

\section{Total Histomorphological Damage Score}

The Sham group demonstrated a significantly lower histomorphological damage score compared with the $I R, I R+D$, and RIPC+IR groups $(p=0.00 I, p=0.00 I, p=0.00 I$, respectively). Comparison between the IR, IR+D, and RIPC+IR groups revealed significant differences $(p=0.005, p=0.009$, respectively). The IR group displayed a significantly higher damage

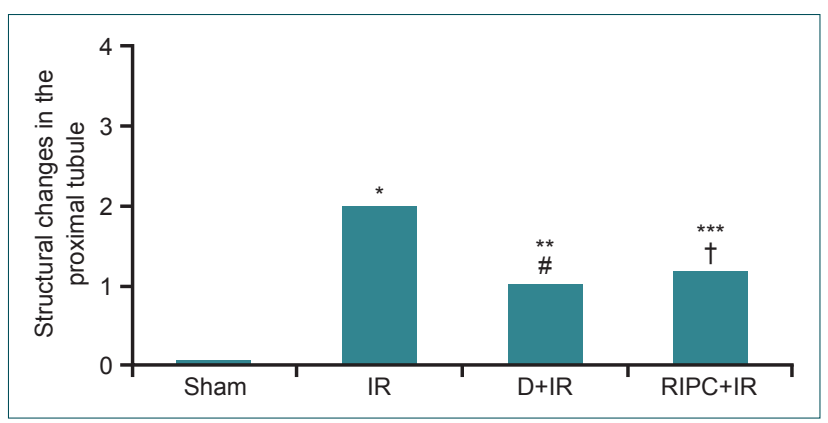

Figure 1. Renal histomorphological evaluation with regard to damage scores in the proximal tubules. ${ }^{*}$ Comparison of IR and Sham groups $(p=0.001)$. ${ }^{* *}$ Comparison of $I R+D$ and Sham groups $(p=0.001) .{ }^{* * *}$ Comparison of IR+RIPC and Sham groups $(p=0.001)$. \# Comparison of IR+D and IR groups $(p=0.006)$. ${ }^{\dagger}$ Comparison of IR+RIPC and IR groups ( $p=0.015)$. D: Dexmedetomidine; IR: Ischemia/reperfusion; RIPC: Remote ischemic preconditioning. score compared with the IR+D and RIPC+IR groups, whereas no significant difference was determined between the $I R+D$ and RIPC+IR groups ( $p=0.89$ ) (Fig. 4).

Sham group samples had normal histomorphological proper-

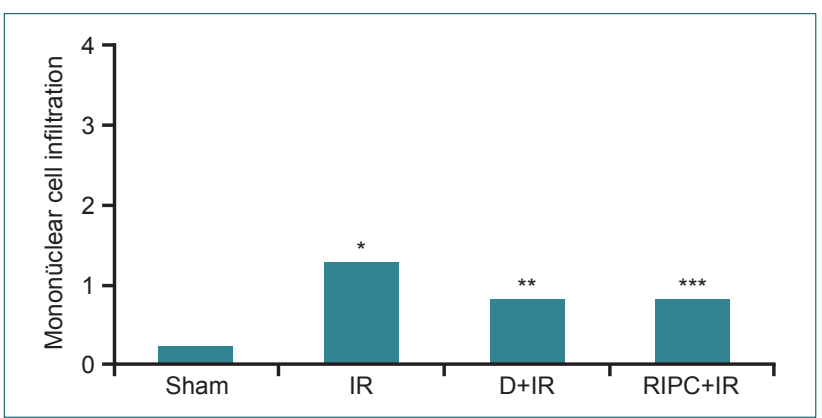

Figure 2. Renal histomorphological evaluation of with regard to mononuclear cell infiltration. *Comparison of IR and Sham groups $(p=0.002) .{ }^{* *}$ Comparison of $I R+D$ and Sham groups $(p=0.002)$. ${ }^{* * *}$ Comparison of IR+RIPC and Sham groups $(p=0.002)$. D: Dexmedetomidine; IR: Ischemia/reperfusion; RIPC: Remote ischemic preconditioning.

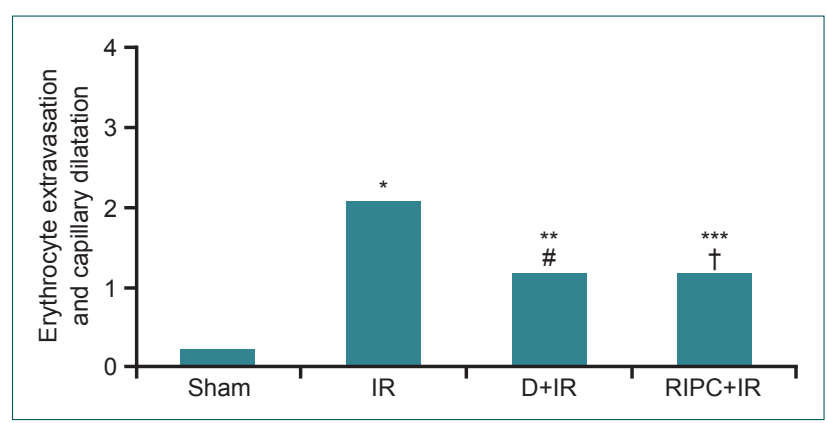

Figure 3. Renal histomorphological evaluation with regard to erythrocyte extravasation and capillary dilatation. *Comparison of IR and Sham groups $(p=0.002)$. ${ }^{* *}$ Comparison of IR+D and Sham groups $(p=0.005) .{ }^{* *}$ Comparison of RIPC+IR and Sham groups $(p=0.005)$. "Comparison of IR+D and IR groups $(p=0.02) .{ }^{\dagger}$ Comparison of IR+RIPC and IR groups $(p=0.02)$. $D$ : Dexmedetomidine; IR: Ischemia/reperfusion; RIPC: Remote ischemic preconditioning.

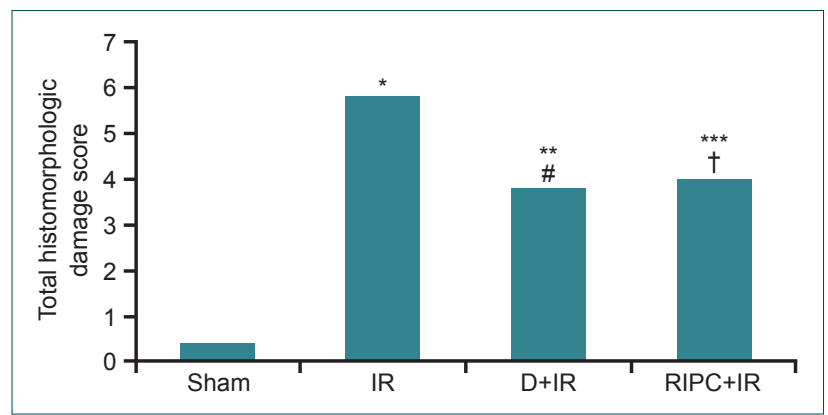

Figure 4. Renal histomorphological evaluation with regard to total histomorphological damage score. ${ }^{*}$ Comparison of IR and Sham groups $(p=0.001)$. ${ }^{* *}$ Comparison of $I R+D$ and Sham groups $(p=0.001) .{ }^{* *}$ Comparison of RIPC+IR and Sham groups $(p=0.001)$. \#Comparison of IR+D and IR groups $(p=0.005)$. ${ }^{\dagger}$ Comparison of IR+RIPC and IR groups ( $p=0.009)$. D: Dexmedetomidine; IR: Ischemia/reperfusion; RIPC: Remote ischemic preconditioning. 
ties and none of the sections in this group exhibited cell infiltration or brush border loss (Figs. 5a, b).

Tubular atrophy, tubular dilatation, mononuclear cell infiltration in the peritubular area, vacuolization, and brush border loss in the proximal tubules were observed in the IR group. In some tubules, proteinaceous material deposits and cast formation was noted, and cellular debris in the tubule lumen was found. Some cortical areas displayed dilated vessels and erythrocyte extravasation (Figs. 6a-d).
Compared with the IR group, the IR+D group demonstrated less tubular atrophy, tubular dilatation, and vacuolization, as well as fewer proteinaceous material deposits and less cast formation in some tubules, cellular debris, and brush border loss in the tubule lumen. There was less mononuclear cell infiltration in the peritubular area and erythrocyte extravasation in the IR+D group than in the IR group (Figs. 7a-d).

Compared with the IR group, the RIPC+IR group demonstrated less degeneration in tubule cells, cortical erythrocyte
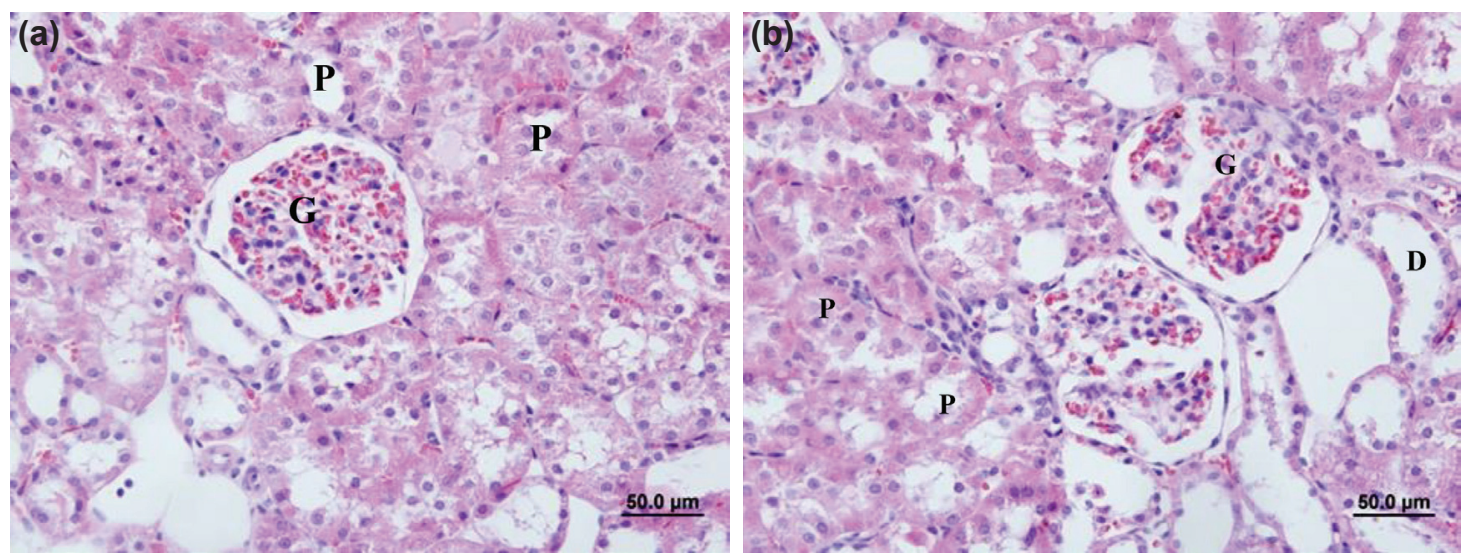

Figure 5. (a, b) Sections from the Sham group. D: Distal tubule; G: Glomerulus; P: Proximal tubule.
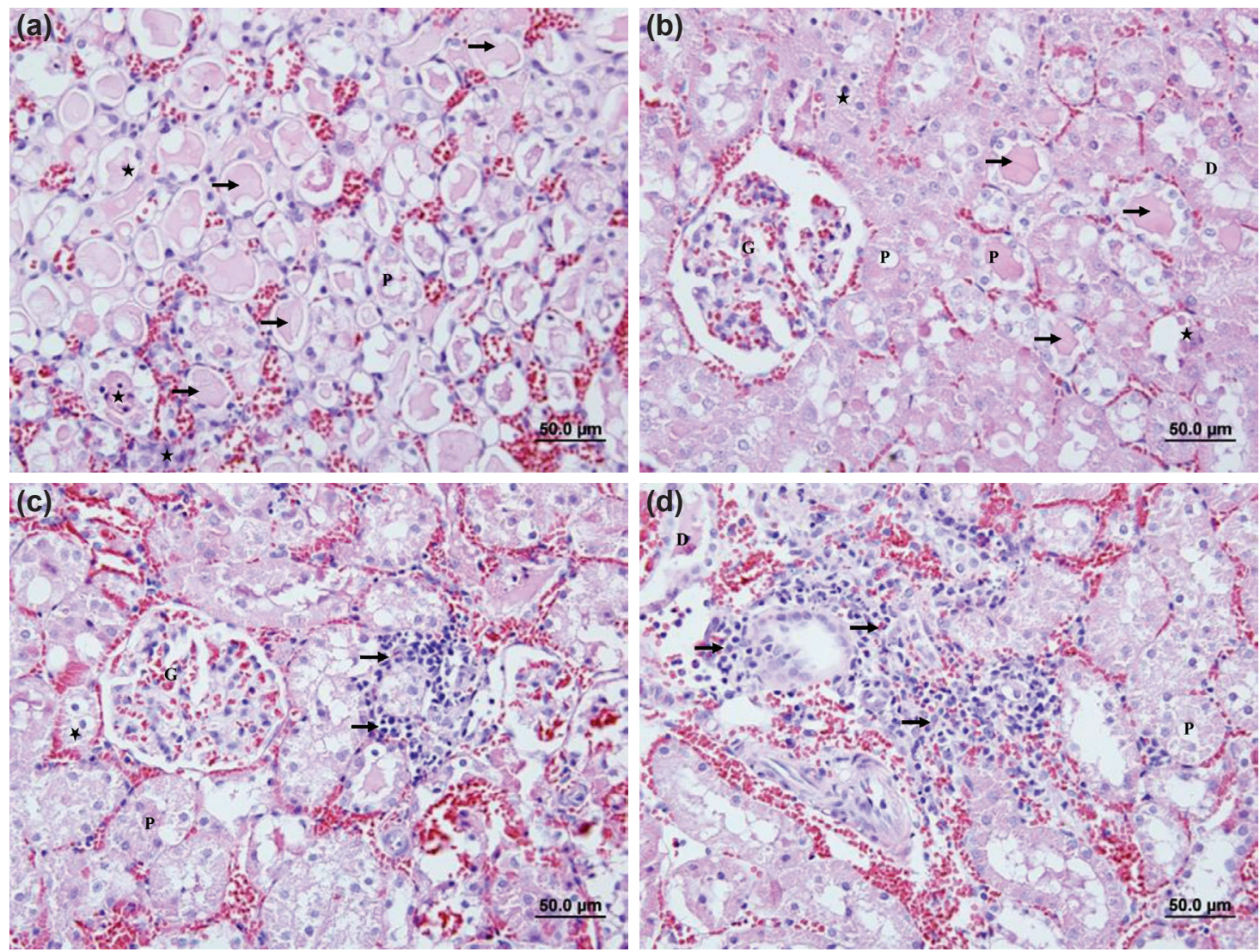

Figure 6. (a, b) Sections from the IR group. $(\rightarrow)$ Accumulation of proteinaceous material in tubules. $\left({ }^{*}\right)$ Proximal tubule epithelial cells in the lumen. (c) Section from the IR group. $(\rightarrow)$ Mononuclear cell infiltration. $\left(^{*}\right)$ Erythrocyte extravasation. (d) Section from the IR group. $(\rightarrow)$ Mononuclear cell infiltration. D: Distal tubule; G: Glomerulus; IR: Ischemia/ reperfusion; P: Proximal tubule. 
extravasation, and mononuclear cell infiltration in the peritubular area. The RIPC+IR group had less brush border loss in the tubules, tubular atrophy, tubular dilatation, vacuolization, proteinaceous material deposits, and cellular debris in the tubule lumen (Figs. 8a, b).
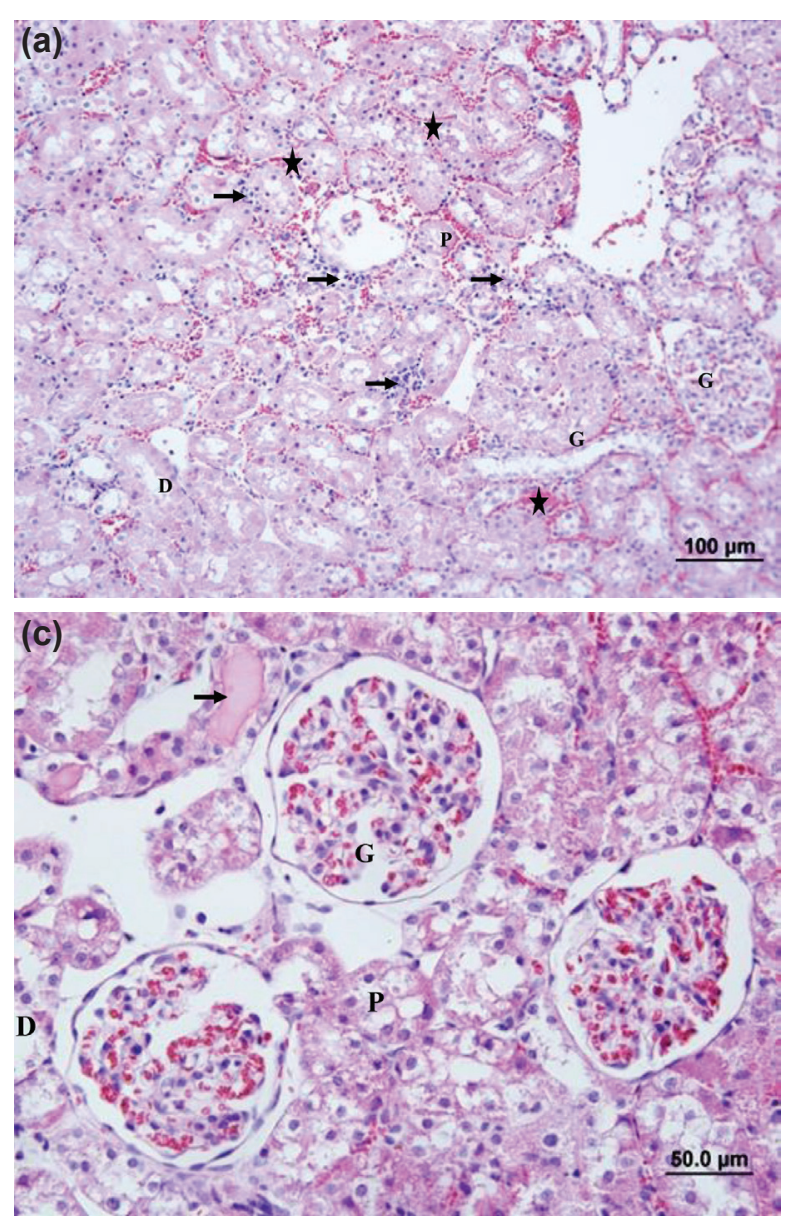

Although comparison between the $I R+D$ and $R I P C+I R$ groups revealed no significant difference, the $I R+D$ group had histomorphologically less brush border loss, tubular atrophy, vacuolization, proteinacious deposits, cast formation, and cellular debris in the tubule lumen.

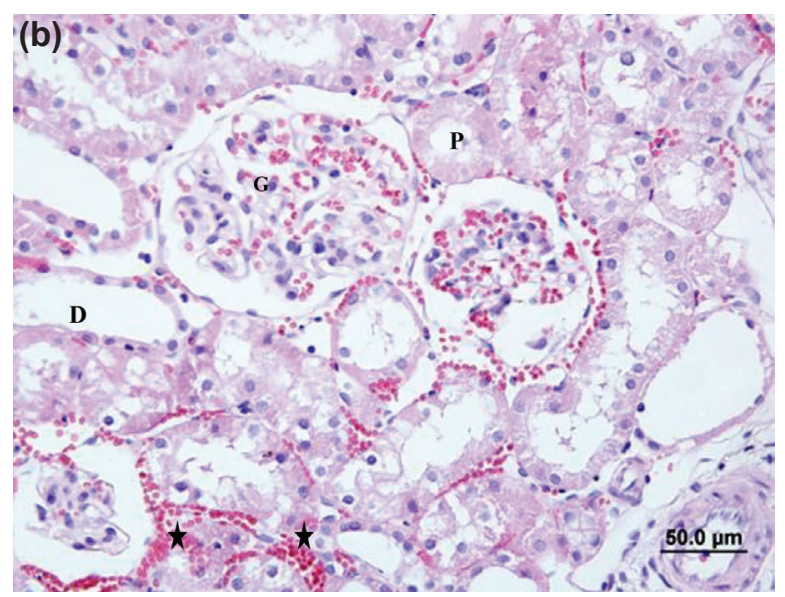

Figure 7. $(\mathbf{a}, \mathbf{b})$ Sections from the IR+dexmedetomidine group. $(\rightarrow)$ Mononuclear cell infiltration. $\left(^{*}\right)$ Erythrocyte extravasation (c, d) Sections from the IR+dexmedetomidine group. $(\rightarrow)$ Accumulation of proteinaceous material in tubules. Proximal tubule epithelial cells in the lumen. D: Distal tubule; G: Glomerulus; IR: Ischemia/reperfusion; P: Proximal tubule.
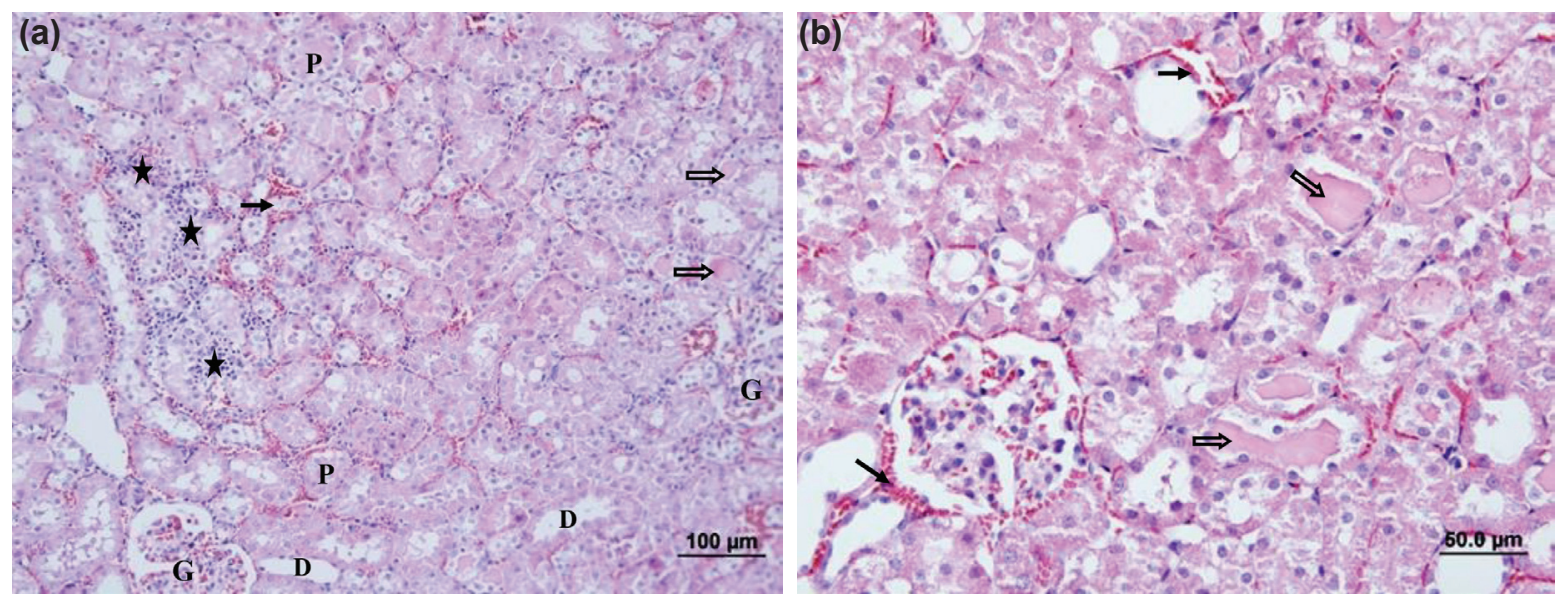

Figure 8. (a, b) Sections from the IR+RIPC group. D: Distal tubule; G: Glomerulus; IR: Ischemia/reperfusion; P: Proximal tubule; RIPC: Remote ischemic preconditioning. $(\rightarrow)$ Erythrocyte extravasation. $\left(^{*}\right)$ Mononuclear cell infiltration. (é) Reduced accumulation of proteinaceous material. 


\section{DISCUSSION}

In this experimental study, the protective effects of RIPC and dexmedetomidine were compared using a rat renal IR mod$\mathrm{el}$, and the results demonstrated that both methods were protective against IR injury. The renal histomorphological total damage score was lower in the IR+D group than in the RIPC+IR group.

In the present study, as in the studies of Williams et al. ${ }^{[14]}$ and Cochrane et al.,, ${ }^{[15]}$ ischemic duration of 45 minutes and reperfusion duration of 4 hours, which allows for observation of earliest renal damage, was performed. The fact that histomorphological damage scores were significantly higher in the IR group than in the Sham group indicated that adequate renal IR damage can be obtained using this model.

Studies illustrating the impact of RIPC in reducing IR damage have presented a noninvasive method to prevent IR damage. Saita et al. ${ }^{[6]}$ noted that the best IPC method for preventing IR damage in skeletal muscle is to apply 3 successive cycles of 10 minutes ischemia +10 minutes reperfusion. Şahin et al. ${ }^{[9]}$ found that 3 cycles of 10 minutes RIPC applied as a tourniquet on the hind leg significantly reduced liver IR damage compared with direct IPC.

In the present study, we elected to use this RIPC method: 3 cycles of 10 minutes ischemia followed by 10 minutes reperfusion via noninvasive tourniquet. When compared with the RIPC group, significantly higher histomorphological total damage scores were observed in the IR group. This result suggests that RIPC may have a protective effect against renal IR damage.

In some experimental studies, pharmacological agents have been used to prevent IR injury. Those drugs are thought to have some effects on the mechanism of IR damage. In pharmacological conditioning method, drugs can be used in prophylaxis (preconditioning) or in treatment (postconditioning). ${ }^{[17-19]}$

Dexmedetomidine is a pharmacological agent that has been used in many experimental studies investigating prevention of IR damage; however, no study related to comparison of effects of dexmedetomidine and RIPC on renal IR injury was found in our PubMed and Excerpta Medica Database search. We chose dexmedetomidine is because it is a safe drug that has been commonly used in anesthesia and critical care practice for many years. Dexmedetomidine could potentially be used in clinical practice to prevent renal IR injury.

Dexmedetomidine has been reported to have protective effects not only against renal ischemia, but also cardiac IR damage and incomplete frontal brain ischemia in rats. ${ }^{[20-23]}$

The exact mechanism of the protective effects of dexmedetomidine against IR damage is not yet known, but in renal tissue, for example, it is believed to increase renal blood flow and glomerular filtration by reducing noradrenaline release. ${ }^{[24]} \mathrm{Gu}$ et al. ${ }^{[25]}$ reported that renal IR damage can be reduced with dexmedetomidine by suppressing the inflammatory cascade via decreasing renal cell death, high mobility group box I protein release, and toll-like receptor 4 . The histopathological impact of this agent on renal IR was first noted by Kocoglu et al. They found that administration of $100 \mu \mathrm{g} / \mathrm{kg}$ ip dose of dexmedetomidine at the beginning of reperfusion therapy reduced the histomorphological damage associated with IR. Similarly, we administered $100 \mu g / \mathrm{kg}$ ip dose of dexmedetomidine 5 minutes after reperfusion. In the present study, the IR group demonstrated significantly higher total damage scores compared with the Sham group. This result indicated appropriate ischemic model.

The results of our study demonstrated histomorphologically that both dexmedetomidine and RIPC decreased renal IR injury significantly. The IR+D group displayed a relatively lower histomorphological total damage score (less tubular atrophy, tubular dilatation, vacuolization, brush border loss in the proximal tubule cells, proteinaceous deposits, cast formation, and cellular debris in the tubule lumen) compared with the RIPC+IR group. This fact may suggest that dexmedetomidine may be a better protector against IR with greater efficacy in decreasing renal damage compared with RIPC.

In conclusion, both methods are noninvasive and easily applicable without increasing the duration of surgery. Further studies should be conducted in future to evaluate the best dosage and administration period.

\section{Conflict of interest: None declared.}

\section{REFERENCES}

1. Collard CD, Gelman S. Pathophysiology, clinical manifestations, and prevention of ischemia-reperfusion injury. Anesthesiology 2001;94:1133-8.

2. Howell JG, Zibari GB, Brown MF, Burney DL, Sawaya DE, Olinde JG, et al. Both ischemic and pharmacological preconditioning decrease hepatic leukocyte/endothelial cell interactions. Transplantation 2000;69:300-3.

3. Paller MS, Hoidal JR, Ferris TF. Oxygen free radicals in ischemic acute renal failure in rat. J Clin Invest 1984;74:1156-64. [CrossRef]

4. Nath KA, Norby SM. Reactive oxygen species and acute renal failure. Am J Med 2000;109:655-78. [CrossRef]

5. Huang SS, Wei FC, Hung LM. Ischemic preconditioning attenuates postischemic leukocyte--endothelial cell interactions: role of nitric oxide and protein kinase C. Circ J 2006;70:1070-5. [CrossRef]

6. Olguner C, Koca U, Kar A, Karci A, Islekel H, Canyılmaz M, et al. Ischemic preconditioning attenuates the lipid peroxidation and remote lung injury in the rat model of unilateral lower limb ischemia reperfusion. Acta Anaesthesiol Scand 2006;50:150-5. [CrossRef]

7. Gueler F, Park JK, Rong S. Statins attenuate ischemia-reperfusion injury by inducing heme oxygenase- 1 in infiltrating macrophages. J Pathol 2007;170:192-9. [CrossRef]

8. Carden DL, Granger DN. Pathophysiology of ischaemia-reperfusion injury. J Pathol 2000;190:255-66. [CrossRef]

9. Şahin E, Olguner Ç, Bodur HA, Koca U, Tuncel P, Ormen M, et al. Com- 
parison of the Effects of the Remote and Direct Ischemic Preconditioning in the Liver Ischemia-Reperfusion Injury. Turkiye Klinikleri JMed Sci 2009;29:381-7.

10. Laurikka J, Wu ZK, Iisalo P, Kaukinen L, Honkonen EL, Kaukinen S, Tarkka MR. Regional ischemic preconditioning enhances myocardial performance in off-pump coronary artery bypass grafting. Chest 2002;121:1183-9. [CrossRef]

11. Takaoka A, Nakae I, Mitsunami K, Yabe T, Morikawa S, Inubushi T, Kinoshita M. Renal ischemia/reperfusion remotely improves myocardial energy metabolism during myocardial ischemia via adenosine receptors in rabbits: effects of "remote preconditioning". J Am Coll Cardiol 1999;33:556-64. [CrossRef]

12. Gertler R, Brown HC, Mitchell DH, Silvius EN. Dexmedetomidine: a novel sedative-analgesic agent. Proc (Bayl Univ Med Cent) 2001;14:1321.

13. Taniguchi T, Kidani Y, Kanakura H, Takemoto Y, Yamamoto K. Effects of dexmedetomidine on mortality rate and inflammatory responses to endotoxin-induced shock in rats. Crit Care Med 2004;32:1322-6. [CrossRef]

14. Williams P, Lopez H, Britt D, Chan C, Ezrin A, Hottendorf R. Characterization of renal ischemia-reperfusion injury in rats. J Pharmacol Toxicol Methods 1997;37:1-7. [CrossRef]

15. Cochrane J, Williams BT, Banerjee A, Harken AH, Burke TJ, Cairns $\mathrm{CB}$, et al. Ischemic preconditioning attenuates functional, metabolic, and morphologic injury from ischemic acute renal failure in the rat. Ren Fail 1999;21:135-45. [CrossRef]

16. Saita Y, Yokoyama K, Nakamura K, Itoman M. Effect of ischaemic preconditioning against ischaemia-induced reperfusion injury of skeletal muscle: how many preconditioning cycles are appropriate. JPlast Surg 2002;55:1-5. [CrossRef]

17. Kocoglu H, Ozturk H, Ozturk H, Yilmaz F, Gulcu N. Effect of dexme- detomidine on ischemia-reperfusion injury in rat kidney: a histopathologic study. Ren Fail 2009;31:70-4. [CrossRef]

18. Frumento RJ, Logginidou HG, Wahlander S, Wagener G, Playford HR, Sladen RN. Deksmedetomidine infusion is associated with enhanced renal function after thoracic surgery.J Clin Anesth 2006;18:422-6. [CrossRef]

19. Villela NR, do Nascimento Júnior P, de Carvalho LR, Teixeira A. Effects of dexmedetomidine on renal system and on vasopressin plasma levels. Experimental study in dogs. Rev Bras Anestesiol 2005;55:429-40.

20. Hoffman WE, Kochs E, Werner C, Thomas C, Albrecht RF. Dexmedetomidine improves neurologic outcome from incomplete ischemia in the rat. Reversal by the alpha 2-adrenergic antagonist atipamezole. Anesthesiology 1991;75:328-32. [CrossRef]

21. Maier CM, Sun GH, Kunis DM, Giffard RG, Steinberg GK. Neuroprotection by the $\mathrm{N}$-methyl-D-aspartate receptor antagonist CGP 40116: in vivo and in vitro studies. J Neurochem 1995;65:652-9. [CrossRef]

22. Kocoglu H, Karaaslan K, Gonca E, Bozdogan O, Gulcu N. Preconditionin effects of dexmedetomidine on myocardial ischemia/reperfusion injury in rats. Curr Ther Res Clin Exp 2008;69:150-8. [CrossRef]

23. Engelhard K, Werner C, Eberspächer E, Bachl M, Blobner M, Hildt E, et al. The effect of the alpha 2-agonist dexmedetomidine and the $\mathrm{N}$-methylD-aspartate antagonist $\mathrm{S}(+)$-ketamine on the expression of apoptosisregulating proteins after incomplete cerebral ischemia and reperfusion in rats. Anesth Analg 2003;96:524-31. [CrossRef]

24. Taoda M, Adachi YU, Uchihashi Y, Watanabe K, Satoh T, Vizi ES. Effect of dexmedetomidine on the release of $[3 \mathrm{H}]$-noradrenaline from rat kidney cortex slices: characterization of alpha2-adrenoceptor. Neurochem Int 2001;38:317-22. [CrossRef]

25. Gu J, Sun P, Zhao H, Watts HR, Sanders RD, Terrando N, et al. Dexmedetomidine provides renoprotection against ischemia-reperfusion injury in mice. Critical Care 2011;15:153. [CrossRef]

\title{
DENEYSEL ÇALIŞMA - ÖZET
}

\section{Deksmedetomidin ve uzak iskemik ön koşullamanın sıçanlarda renal iskemi reperfüzyon hasarı üzerine koruyucu etkileri \\ Dr. Cansu Balcı, ${ }^{1}$ Dr. Mert Akan, ${ }^{2}$ Dr. Nilay Boztaş, ${ }^{3}$ Dr. Sevda Özkardeşler, ${ }^{3}$ \\ Dr. Bekir Uğur Ergür, ${ }^{4}$ Dr. Mustafa Ensari Güneli, ${ }^{5}$ Dr. Belgin Ünal ${ }^{6}$}

\author{
${ }^{1}$ Çanakkale Devlet Hastanesi, Anesteziyoloji ve Reanimasyon Kliniği, Çanakkale \\ ${ }^{2}$ Kent Hastanesi, Anesteziyoloji ve Reanimasyon Kliniği, İzmir \\ ${ }^{3}$ Dokuz Eylül Üniversitesi Tıp Fakültesi, Anesteziyoloji ve Reanimasyon Bilim Dalı, İzmir \\ ${ }^{4}$ Dokuz Eylül Üniversitesi Tıp Fakültesi, Histoloji ve Embriyoloji Anabilim Dalı, İzmir \\ ${ }^{5}$ Dokuz Eylül Üniversitesi Tıp Fakültesi, Deney Hayvanları Bilim Dalı, İzmir \\ ${ }^{6}$ Dokuz Eylül Üniversitesi Tıp Fakültesi, Halk Sağlığı Anabilim Dalı, İzmir
}

AMAÇ: Şok, böbrek transplantasyonu, kısmi nefrektomi, kardiyopulmoner baypas, sepsis gibi çeşitli klinik durumlarda ortaya çıkabilen iskemi reperfüzyon (IR) hasarı hastada ciddi organ yetersizliklerine neden olabilmektedir. İskemi reperfüzyon hasarını azaltmak amacıyla kullanılan yöntemlerden bazıları uzak iskemik ön koşullama (UiÖK) ve farmakolojik koşullamadır. Bu çalışmanın amacı; sıçan renal iR modelinde tek taraflı arka ekstremiteye uygulanacak UiÖK ile farmakolojik koşullama olarak deksmedetomidin kullanımının etkilerinin karşılaştııııasıdır.

GEREÇ VE YÖNTEM: Dokuz Eylül Üniversitesi Tıp Fakültesi Hayvan Deneyleri Yerel Etik Kurulu onayı alındıktan sonra ağırlıkları 250-300 g arasında değişen 28 adet erkek Wistar albino sıçan her birinde yedişer denek olacak şekilde dört gruba ayrıldı. Tüm gruplara genel anestezi altında laparotomi uygulandı ve sol renal pedikül diseke edildi. Grup I (Sham, n=7): Laparatomi sonrası sol renal pedikül diseke edilip başka bir girişim yapılmadan sıçanlar anestezi altında bekletildi. Grup II (iR, n=7): Laparotomi sonrasında sol böbreğe 45 dakika total iskemi sonrası dört saat reperfüzyon uygulandı. Grup III (IR+ Deksmedetomidin, $n=7$ ): Laparotomi sonrasında sol böbreğe İskemi uygulanırken reperfüzyonun beşinci dakikasında I00 $\mu \mathrm{g} / \mathrm{kg}$ deksmedetomidin intraperitoneal verildi. Grup IV (UiÖK+iR, n=7): Anestezi altında sol arka bacağa üç döngü 10 dakika iskemi ve 10 dakika reperfüzyon uygulananarak beş dakika sonra sol böbrekte IR oluşturuldu. Tüm gruplarda ratların anestezi süresi eşit tutuldu, histomorfolojik değerlendirme için sol böbrek çıkarıldıktan sonra sıçanlar sakrifiye edildi.

BULGULAR: Böbrek histomorfolojik hasar toplam skoru Sham grubunda diğer gruplara göre anlamlı olarak düşük bulundu $(p<0.0 \mathrm{I})$. İskemi reperfüzyon grubundaki histomorfolojik hasar toplam skorları IR+deksmedetomidin ve UiÖK+iR gruplarından anlamlı olarak yüksek saptandı ( $p<0.0 \mathrm{I})$. Deksmedetomidin ve UiÖK gruplarının hasar skorları karşılaştıııldığında anlamlı bir fark saptanmadı $(p=0.89)$.

TARTIŞMA: Bu deneysel çalışmada, sıçan renal IR modelinde deksmedetomidin ve UiÖK'nin IR hasarını histomorfolojik olarak anlamlı düzeyde azalttığı saptanırken, IR+deksmedetomidin ve UïÖK+iR grupları arasında anlamlı bir fark bulunmadı.

Anahtar sözcükler: Böbrek; deksmedetomidin; iskemi reperfüzyon hasarı; uzak iskemik ön koşullama.

Ulus Travma Acil Cerrahi Derg 2017;23(4):279-286 doi: 10.5505/tjtes.2016.49103 